\title{
Arsen i njegovi spojevi: otrovi, pigmenti, lijekovi
}

\section{G. Pavlović *}

Tekstilno-tehnološki fakultet Sveučilišta u Zagrebu, Prilaz baruna Filipovića 28a, 10000 Zagreb

\begin{abstract}
Sažetak
Arsen je polumetal (element 15. skupine elemenata u Periodičkoj tablici elemenata), te je očekivano da će tvoriti čitav niz spojeva različitih svojstava s obzirom na vrstu kemijske veze i strukturu. U kemijskim reakcijama iskazuje metalna i nemetalna svojstva. S obzirom na Paulingov koeficijent elektronegativnosti sličan nemetalima, tvori stabilne kovalentne spojeve i s najelektronegativnijim elementima, u spojevima stvara stabilnu kovalentnu vezu As-As te tvori organoarsenove spojeve sa stabilnom vezom As-C. Primjena arsenovih spojeva bila je u prošlosti raznovrsna i višestruka. Povijesni pregled otkrivanja i uporabe arsenovih spojeva jasno poučava da se razvoj spoznaja o kemiji arsena i arsenovih spojeva temelji na znanstvenim otkrićima i napretku znanosti općenito. Organoarsenovi spojevi u prošlosti rabljeni kao lijekovi, kasnije su, razvojem znanosti, odbačeni kao otrovni i zamijenjeni naprednijim, modernijim lijekovima čija se svojstva i uporaba više ne zasnivaju na empiriji. Anorganski spojevi arsena (posebice arsenovi sulfidni minerali) primjenjivali su se kao anorganski pigmenti u slikarstvu. Takvi primjeri upotrebe spojeva kroz povijest mogu se primijeniti u srednjoškolskoj nastavi kao primjer međupredmetnih tema u kojima se povezuje kemija arsena s ekološkim i toksikološkim temama te u povijesti umjetnosti. Slično postoji i u visokoškolskom obrazovanju, posebice gdje se izučava primijenjena anorganska kemija ili u povijesti medicine i farmakologije.
\end{abstract}

Ključne riječi

Kemija arsena, arsenovi spojevi kao otrovi, pigmenti i lijekovi, ekotoksikologija, nastava kemije

\section{Uvod}

Kemija arsena i njegovih spojeva ne poučava se u okviru srednjoškolske izobrazbe kemije, osim u preglednom smislu kemije 15. skupine elemenata periodičke tablice elemenata i njihovih spojeva, dok je u visokoobrazovnoj nastavi kemije prisutna (u kolegijima anorganske kemije kad se govori o sistematizaciji elemenata i spojeva 15. skupine elemenata), ali se izbjegava rad sa spojevima arsena u laboratorijima.

Razlog tomu je razumljiv s obzirom na otrovnost elementa i njegovih spojeva. No to ne znači da kemiji arsena i njegovih spojeva ne treba posvetiti izvjesnu pozornost u srednjoškolskoj izobrazbi kemije iz povijesnih, ekoloških i općih kulturoloških razloga. Naime, mnogi kemijski elementi i njihovi spojevi primjenjivali su se u prošlosti u različitim područjima ljudskog djelovanja, od ljekarništva i medicine, poljoprivrede, u različitim industrijskim primjenama $\mathrm{i}$ slično, jer se tada njihova kemija nije dovoljno poznavala i bila je poglavito empirijske naravi. Danas takve primjene u prošlosti izučavamo kao dobre primjere razvoja znanosti i sagledavamo ih u kontekstu vremena u kojem su imali određeno značenje.

Kemija arsena i njegovih spojeva zanimljiva je u tom kontekstu sa stanovišta primjene u ljekarništvu i medicini kao

*Prof. dr. sc. Gordana Pavlović

e-pošta: gordana.pavlovic@ttf.unizg.hr i u industriji anorganskih pigmenata, pa je stoga posebice zanimljiva za izučavanje farmaceutima, medicinarima, posebice ekolozima kad je u pitanju zagađenje izvora pitkih voda ili pak u tehnologiji primjene anorganskih pigmenata, slikarstvu, tekstilnoj i poluvodičkoj industriji.

\section{Općenito o arsenu}

Arsen je kemijski element 15. skupine kemijskih elemenata i 4. periode periodičke tablice elemenata (poznate i pod nazivom pniktogeni elementi), čiji je glavni predstavnik dušik, a uz fosfor članovi te skupine su i antimon te bizmut. Postoji samo jedan stabilan izotop arsena.

Smatra se da je arsen izolirao Albertus Magnus (1193. - 1280.) zagrijavanjem sulfida arsena formule $\mathrm{As}_{2} \mathrm{~S}_{3}$ sa sapunom. Čini se da sam naziv za element potječe od latinskog izvornika arsenicum od grčkog arsenicon, koji pak potječe od perzijskog naziva az-zarnikh - zar=zlato; upućujući na žutu boju spoja $\mathrm{As}_{2} \mathrm{~S}_{3}$, važnog anorganskog spoja i rude arsena. ${ }^{1}$

Arsen postoji u tri alotropna oblika. ${ }^{1}$ Elementni arsen proizvodi se termičkim razlaganjem ili prženjem (oksidacija) sulfidnih ruda. Pri tome nastaje elementni arsen u obliku četveroatomne homonuklearne molekule $\mathrm{As}_{4}$ ("žuta ili $\alpha$ modifikacija") koja je strukturni analogon alotropskoj modifikaciji fosfora $\mathrm{P}_{4}$ (tetraedar). Žuti arsen nastaje naglim 
hlađenjem arsenovih para, ali brzo i lako prelazi u stabilniju "sivu" metalnu modifikaciju polimerne strukture koja kristalizira u romboedarskom kristalnom sustavu.

Treća forma, "crni" arsen pak ima strukturu crvenog fosfora.

Upotreba arsena kao otrova u 19. i na početku 20. stoljeća bilo je česta, jer se mogao lako pribaviti kao sredstvo za uništavanje korova ili ubijanje štetnih kukaca, a simptomi trovanja bili su opći i lako su se mogli zamijeniti sa simptomima neke bolesti. ${ }^{2}$

Arsen je polumetal, ali ga ekolozi svrstavaju u skupinu "teških" metala zajedno s kadmijem, živom i olovom. Zacijelo, toksičnost arsena i njegovih spojeva, uz ekološku relevantnost, svrstavaju arsen u skupinu "teških metala".

Arsen je (poput antimona i bizmuta) halkofilan, pa ga u Zemljinoj kori najčešće nalazimo u obliku sulfida (poput spomenutog minerala $\mathrm{As}_{2} \mathrm{~S}_{3}$, žutog arsenova blistavca ili auripigmenta - naziv potječe od žute boje slične boji zlata), a često se pojavljuje zajedno s drugom sulfidnom rudom arsena, realgarom, $\mathrm{As}_{4} \mathrm{~S}_{4}$. Realgar, monoklinski mineral, poznat je i pod nazivom crveni arsenov blistavac. Realgar raspadom daje auripigment. Arsen je ponekad prisutan $\mathrm{u}$ formi minerala arsenolita, $\mathrm{As}_{2} \mathrm{O}_{3}$ odnosno $\mathrm{As}_{4} \mathrm{O}_{6}$. Arsenovi sulfidi česti su pratioci bakrenih ruda. $U$ prirodi ga nalazimo i kao FeAsS, mineral arsenopirit. Osim u obliku sulfida, arsen u prirodi možemo naći u međumetalnim spojevima $\mathrm{s}$ anitmonom i bakrom.

Zanimljivo kako je uvriježeno mišljenje da je bronca prva otkrivena slitina. ${ }^{3}$ Akademik D. Grdenić u svojoj čuvenoj knjizi Povijest kemije navodi da je to bila slitina bakra i arsena; naime, arsen je čest pratilac bakra u Zemljinoj kori. Taljenjem rude bakra (a bakar je u to doba bio izrazito tražen) s određenim sadržajem arsena taložio se bijeli oblog, sublimat arsenika, $\mathrm{As}_{2} \mathrm{O}_{3} .{ }^{3}$ D. Grdenić o tome piše: "Talioničari su poznavali rude koje su se tako ponašale pri prženju, pa su ih dodavali bakarnoj rudi da bi proizveli novu vrstu bakra, zapravo slitinu bakra s arsenom. Bila je to arsenska bronca, prethodnica prave, kositrene bronce." ${ }^{3}$ Smatralo se da arsen u arsenskoj bronci poboljšava kvalitetu bakra. Arsenska bronca imala je dobru kovkost, a tvrdoću poput čelika. Proizvodnja arsenske bronce napuštena je i zamijenjena kositrenom kad se uvidjelo da talioničari obolijevaju i umiru od para arsena i arsenika. ${ }^{3}$

Po zastupljenosti u Zemljinoj kori je 53. element. Najviše ga ima u tlu (1 - $10 \mathrm{ppm})$, a gotovo tisuću puta manje (oko 1,6 ppb) u morskoj vodi. U ljudskom tijelu najviše se nakuplja u kosi (oko $1 \mathrm{ppm}$ ) i krvi $\left(2-9 \mu \mathrm{gl}^{-1}\right)$, a manje u kostima. Ukupno ga u prosjeku u ljudskom tijelu ima oko 7 mg. ${ }^{1}$

Arsen nalazimo u podzemnim vodama Indije, Kine, Bangladeša, Filipina, Tajvana, gdje je prisutan u koncentracijama od 400 do $3400 \mu \mathrm{I}^{-1}$, u Čileu, Meksiku i Argentini od 140 do $300 \mathrm{\mu g} \mathrm{l}^{-1}$. U termalnim vodama Novog Zelanda bilježi se prisutnost od čak $8,5 \mathrm{mgl}^{-1}$, a u nas ga ima najviše u podzemnim vodama (bunari) istočnog dijela Slavonije.

U hrani ga najviše nalazimo u ribama, školjkama poput kamenica (oko 4 ppm), a posebice u dagnjama (oko
120 ppm), dok ga najviše ima u rakovima (oko 175 ppm). No relativno se lako izlučuje urinom jer se u obliku arsenobetaina (analog trimetilglicina) apsorbira u crijevima. ${ }^{2}$

Prvo masovno trovanje arsenom putem hrane (i pića) zabilježeno je u Manchesteru, u Engleskoj kada je ustanovljeno da su veće količine arsena u pivu uzrokovane zbog načina proizvodnje invertnog šećera, za čiju proizvodnju je rabljena sumporna kiselina dobivena iz željezova pirita koji je sadržavao arsenov pirit (čest pratilac sulfidnih ruda). ${ }^{2} \mathrm{Od}$ 6000 ljudi koji su konzumirali pivo, umrlo je 70.

Većina žitarica, voća i povrća sadržava 0,1 - 1,0 mg arsena po kg suhe tvari jer je često arsen sastavni dio pesticida. To posebice predstavlja problem u zemljama u kojima je riža osnova prehrane stanovništva, poput Kine, jer se pokazalo da se arsen naročito nakuplja u riži.

Poput drugih "teških" metala arsen pokazuje učinak bioakumulacije i nakupljanja u tkivima riba u obliku metiliranih arsenovih spojeva.

lako se stoljećima rabio kao otrov i sastavni dio nekih pigmenata, a prije otkrića penicilina i kao lijek, zahvaljujući sposobnosti uništavanja mikroorganizama, u današnje vrijeme je najveći izvor onečišćenja arsenom njegova uporaba u pesticidima.

U prošlosti se rabio u smjesama u kozmetičke svrhe, za izbjeljivanje kože. Naročito je bila popularna uporaba arsena u 18. stoljeću kada se rabio kao "Fowlerova otopina" s kojom je dr. Fowler liječio pacijente s groznicom. Otopina se pila i radi općeg jačanja organizma. Jedna litra vodene otopine pripravljala se otapanjem $10 \mathrm{~g} \mathrm{As}_{2} \mathrm{O}_{3}$ (možda najpoznatiji spoj arsena, poznat i pod nazivom arsenik), 7,6 $\mathrm{g} \mathrm{KHCO}_{3}$ i $30 \mathrm{ml}$ etanola. ${ }^{2}$ Par kapi otopine dodavalo se vinu ili vodi. Preporučivala se i kao afrodizijak.

Zemlje koje danas najviše proizvode oksid arsena, a zatim i elementni arsen su Francuska, Švedska, Rusija i Čile, a nekada SAD.

Elementni arsen najviše se rabi u legurama s olovom, manje s bakrom, za izradu baterija, dok se međumetalni spojevi poput GaAs i InAs rabe u izradi LED dioda, laserskih prozora, tunelnih dioda, infracrvenih emitera. ${ }^{1}$

\section{Anorganski spojevi arsena - otrovnost i primjena}

Arsen se u spojevima pojavljuje u oksidacijskim stanjima III i V, pri čemu su kako anorganski tako i organoarsenovi spojevi u oksidacijskom stanju III otrovniji od onih u oksidacijskom stanju V.

Najvažniji anorganski spojevi arsena su oni s vodikom, kisikom, sumporom i halogenim elementima (poput arsenovih klorida) (tablica 1). Unatoč metaloidnom karakteru, arsen gradi kovalentne spojeve s većinom nemetala, dok s metalima tvori međumetalne spojeve, a ne arsenide (koji bi sadržavali $\mathrm{As}^{3-}$ ion poput fosfida i nitrida). Tako ne postoji niti $\mathrm{As}^{3+} \mathrm{u}$ čvrstom stanju jer je spoj $\mathrm{AsF}_{3}$ izrazito kovalentne prirode, iako je fluor najelektronegativniji element. ${ }^{4}$ 
Tablica 1 - Najvažniji anorganski spojevi arsena

Table 1 -Most important inorganic compounds of arsenic

\begin{tabular}{|c|c|c|c|}
\hline & Kemijska formula & Kemijski naziv & $\begin{array}{l}\text { Oksidacijski } \\
\text { broj arsena }\end{array}$ \\
\hline $\begin{array}{l}\text { spojevi s } \\
\text { vodikom }\end{array}$ & $\mathrm{AsH}_{3}$ & arsenovodik (arsin) & $\begin{array}{l}\text { - III (tradicijski } \\
\text { zbog analogije } \\
\text { s amonijakom) }\end{array}$ \\
\hline oksidi & $\begin{array}{c}\mathrm{As}_{2} \mathrm{O}_{3} \text { (u plinskoj } \\
\text { fazi dimerizira u } \\
\left.\mathrm{As}_{4} \mathrm{O}_{6}\right) \\
\mathrm{As}_{2} \mathrm{O}_{5}\left(\mathrm{As}_{4} \mathrm{O}_{10}\right)\end{array}$ & $\begin{array}{l}\operatorname{arsenov}(\mathrm{III}) \text { oksid } \\
\operatorname{arsenov}(\mathrm{V}) \text { oksid }\end{array}$ & $\begin{array}{l}\text { III } \\
\mathrm{V}\end{array}$ \\
\hline $\begin{array}{l}\text { kiseline i } \\
\text { soli }\end{array}$ & $\begin{array}{l}\mathrm{H}_{3} \mathrm{AsO}_{3} \\
\mathrm{H}_{3} \mathrm{AsO}_{4}\end{array}$ & $\begin{array}{l}\text { arsenasta kiselina, } \\
\text { soli: arseniti } \\
\text { arsenska kiselina, } \\
\text { soli: arsenati }\end{array}$ & $\begin{array}{l}\text { III } \\
\text { V }\end{array}$ \\
\hline sulfidi & $\begin{array}{l}\mathrm{As}_{2} \mathrm{~S}_{3} \\
\mathrm{As}_{4} \mathrm{~S}_{4}\end{array}$ & & $\begin{array}{l}\text { III } \\
\text { II }\end{array}$ \\
\hline halogenidi & $\begin{array}{c}\mathrm{AsF}_{3} \\
\mathrm{AsF}_{5} \\
\mathrm{AsCl}_{3} \\
\mathrm{AsCl}_{5} \\
\mathrm{AsBr}_{3} \\
\mathrm{Asl}_{3} \\
\mathrm{As}_{2} \mathrm{I}_{4}\end{array}$ & & $\begin{array}{l}\text { III } \\
\text { V } \\
\text { III } \\
\text { V } \\
\text { III } \\
\text { III } \\
\text { II }\end{array}$ \\
\hline
\end{tabular}

Spoj arsena s vodikom naziva se arsin (arsenovodik), formule $\mathrm{AsH}_{3}$, najotrovniji je spoj arsena i smatra se jednim od najotrovnijih anorganskih spojeva uopće. To je plin mirisa po češnjaku, što omogućuje njegovo brzo otkrivanje. Termički je nestabilan i raspada se pri $250-300{ }^{\circ} \mathrm{C}$. Struktura molekule analogna je strukturi amonijaka (deformirani tetraedar odnosno trostrana piramida). Jak je reducens $\mathrm{i}$ slabo topljiv u vodi (zbog slabog afiniteta prema protonu ne stvara vodikove veze, za razliku od amonijaka). Danas se upotrebljava u industriji proizvodnje poluvodiča u strogo kontroliranim uvjetima.

Arsin ima povijesno značenje jer je 1836. James Marsh (slika 1) otkrio metodu kojom se mogu dokazati male količine arsena. ${ }^{5}$ Metoda je poznata u kemijskoj literaturi pod nazivom Marshova proba, a temelji se na redukciji arsenova(III) oksida, $\mathrm{As}_{2} \mathrm{O}_{3}$, cinkom u kiselom mediju, pri čemu nastaje arsin koji se zagrijavanjem raspada na elemente.

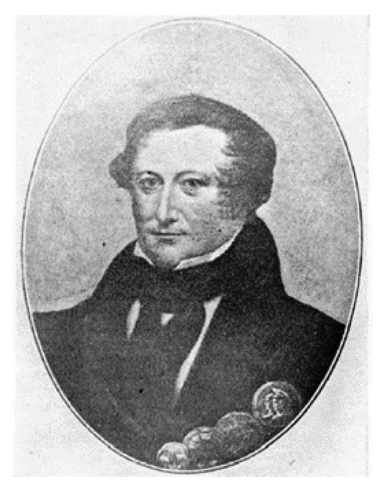

Slika 1 - James Marsh, britanski kemičar, (1794. - 1846.)

Fig. 1 - James Marsh, British chemist, (1794-1846)
Na ugrijanoj staklenoj površini termičkim raspadom arsina (arsenovodika), $\mathrm{AsH}_{3}$, dolazi do isparavanja arsena čije pare stvaraju (zrcalni) nanos tzv. "arsensko ogledalo", pa se Marshovom probom lako uočava. Tako je moguće otkriti mase i manje od 0,1 $\mu$ g.

Arsenovi oksidi, $\mathrm{As}_{2} \mathrm{O}_{3}$ arsenov(III) oksid, i $\mathrm{As}_{2} \mathrm{O}_{5}$, arse$\operatorname{nov}(\mathrm{V})$ oksid, karcinogeni su 1. skupine, što znači da je njihovo karcinogeno djelovanje dokazano u čovjeka, a ne samo u životinja. Danas se smatra da većina trovanja potječe od $\mathrm{As}_{2} \mathrm{O}_{3}$, a ne od znatno otrovnijeg $\mathrm{AsH}_{3}$ upravo zbog gore istaknute strogo kontrolirane uporabe $\mathrm{AsH}_{3}$.

$\mathrm{As}_{2} \mathrm{O}_{3}$ postoji kao mineral arsenolit koji kristalizira u kubičnom sustavu kao $\mathrm{As}_{4} \mathrm{O}_{6}$, dok monoklinski poznat kao mineral klaudetit sadrži $\mathrm{As}_{2} \mathrm{O}_{3}$ jedinice. Pare arsenova(III) oksida sadrže $\mathrm{As}_{4} \mathrm{O}_{6}$ molekule izostrukturne $\mathrm{s}_{4} \mathrm{O}_{6}$.

Arsenov oksid $\mathrm{As}_{2} \mathrm{O}_{3}$ je "amfoteran" (prema podjeli oksida po njihovim kiselo-baznim svojstvima) za razliku od fosforovih oksida. To se ogleda u kemijskim reakcijama u neutralnom ili kiselom mediju, pri čemu nastaje arsenitna kiselina, $\mathrm{H}_{3} \mathrm{AsO}_{3} \mathrm{i}$ arsenatna, $\mathrm{H}_{3} \mathrm{AsO}_{4}$. Bolja mu je topljivost u bazičnom mediju.

Triprotonska arsenasta kiselina vrlo je slaba, poput borne ( $p K_{\text {a }}$ oko 9,2 za prvi stupanj disocijacije).

Postoji u orto- $\left(\mathrm{H}_{3} \mathrm{AsO}_{3}\right)$ i meta-obliku $\left(\mathrm{HAsO}_{2}\right)$, pri čemu meta-oblik predstavlja monoprotonsku kiselinu. Soli arsenaste kiseline, arseniti i derivati rabili su se u povijesti ljekarništva i medicine kao lijekovi, a neki od njih i kao anorganski pigmenti ponajviše u slikarstvu.

Bakrovi arseniti rabili su se kao zeleni anorganski pigmenti: pariško zeleno je pigment formule $\left[\mathrm{Cu}\left(\mathrm{C}_{2} \mathrm{H}_{3} \mathrm{O}_{2}\right)_{2}\right.$. $3 \mathrm{Cu}\left(\mathrm{AsO}_{2}\right)_{2}$ ] (slika 2), dok je Scheeleovo zeleno pigment bakrov hidrogenarsenit formule $\mathrm{CuHAsO}$.
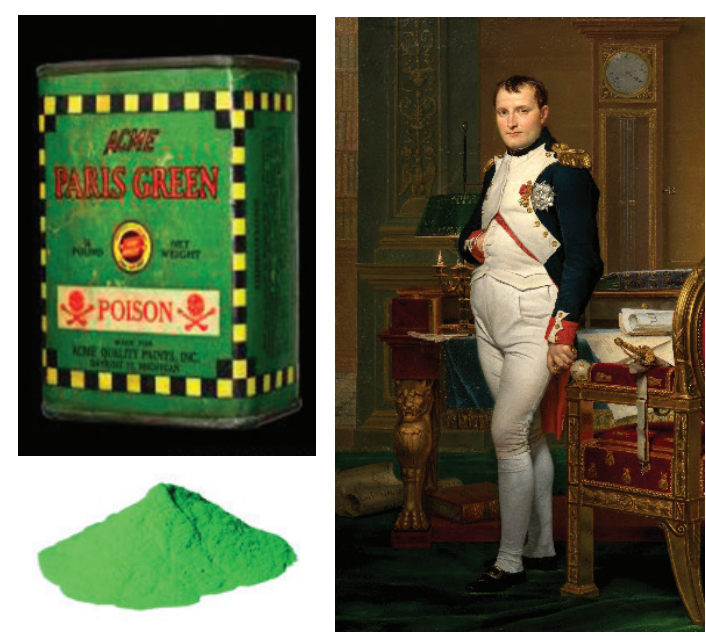

Prema: https://sh.wikipedia.org/wiki/Napoleon_I_Bonaparte Slika 2 -Pariško zeleno, pigment formule $\left[\mathrm{Cu}\left(\mathrm{C}_{2} \mathrm{H}_{3} \mathrm{O}_{2}\right)_{2} \cdot 3 \mathrm{Cu}\left(\mathrm{AsO}_{2}\right)_{2}\right]$, povezan je sa smrću Napoleona I Bonapartea (fotografija oko 182. g.)

Fig. 2 - Paris green, pigment of formula $\left[\mathrm{Cu}\left(\mathrm{C}_{2} \mathrm{H}_{3} \mathrm{O}_{2}\right)_{2} \cdot 3 \mathrm{Cu}\left(\mathrm{AsO}_{2}\right)_{2}\right]$, which is connected with the death of Napoléon I Bonaparte 
Smrt Napoleona I Bonapartea (Ajaccio, 15. kolovoza 1769. - Sveta Helena, 5. svibnja 1821.) na Korzici i danas je predmet izučavanja i različitih tumačenja. Dokazano postojanje tragova arsena u kosi 60.-ih godina 20. stoljeća (Marshov pokus otkriven je 15 godina nakon Napoleonove smrti) stvorilo je pretpostavku da je namjerno i sustavno trovan arsenovim spojevima čiji izvori su bili vino, otrov za miševe ili tapete koje su bile zelene boje, što je potjecala od pigmenta pariškog zelenog (smaragdna zelena, Schweinfurt zelena, CI Pigment Green 21), koji se tada intenzivno upotrebljavao kao zelena boja. Tek 60.-ih godina 20. stoljeća otkrivena je njegova otrovnost. Nastaje sintezom bakrova(II) acetata i arsenova trioksida.

Posebno je ovaj pigment bio popularan među impresionistima i postimpresionistima (Paul Cézanne, Vincent van Gogh, Oscar-Claude Monet, Paul Gauguin) (slike 3 i 4).

No pariškom zelenom prethodila je sinteza prvog anorganskog pigmenta koji je sadržavao arsen i bakar, Scheeleovo zeleno (Cl Pigment zeleno 22) 1775. g. Carl Wilhelm Scheele, švedski kemičar, slučajno ga je otkrio baveći se istraživanjima na arsenu i njegovim spojevima. Taj pigment ima varijabilan kemijski sastav ovisno o omjeru bakar : arsen (svjetlija boja se javlja kad je veći sadržaj arsena), na koji utječu polazni prekursori u sintezi (natrijev karbonat, modra galica, arsenov trioksid, arsenik) i temperatura, a boja mu varira od blijede žuto-zelene do tamnozelene. ${ }^{6}$

Danas se ti anorganski spojevi arsena više ne upotrebljavaju kao pigmenti, možebitno u manje razvijenim zemljama kao insekticidi. ${ }^{6}$

$\mathrm{As}_{2} \mathrm{O}_{5}$ je složene strukture koja se sastoji od međusobno povezanih oktaedara $\left\{\mathrm{AsO}_{6}\right\}$ i tetraedara $\left\{\mathrm{AsO}_{4}\right\} . \mathrm{As}_{2} \mathrm{O}_{5}$ je termički nestabilan i jak oksidans, dobro topljiv u vodi, pri

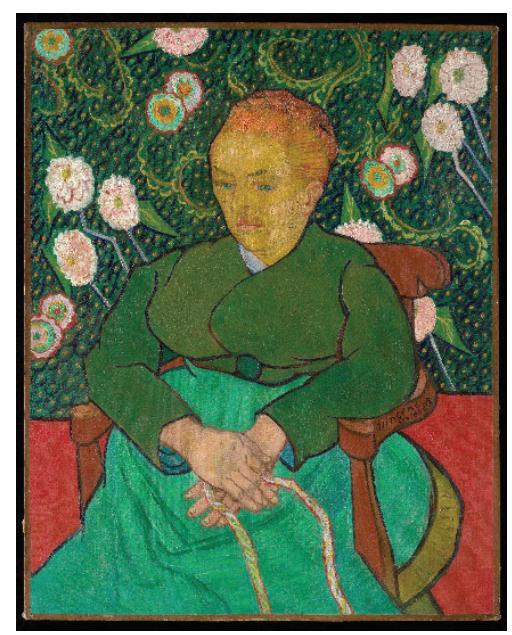

Prema: https://www.metmuseum.org/art/collection/ search/437984

Slika 3 - Vincent van Gogh, Gospođa Roulin ljulja se u kolijevci, 1889., Institut umjetnosti, Chicago, Sjedinjene Američke Države. Vidljiva je uporaba Pariškog zelenog na prikazu suknje.

Fig. 3 - Vincent van Gogh, Madame Roulin Rocking the Cradle, 1889, Art Institute, Chicago, USA. The use of Paris green on the skirt representation. čemu nastaje arsenska kiselina. Arsenska kiselina je triprotonska, pri čemu je $p K_{a}$ oko 2,2 za prvi stupanj disocijacije. Arsenska kiselina je srednje jaka kiselina, nešto slabija od fosforne, ali je jači oksidans od fosforne. Poznat je i meta-oblik formule $\mathrm{HAsO}_{3}$.

Arsenati su upotrebljavani kao insekticidi na pamuku, voćkama, krumpiru, a kalijev dihidrogenarsenat, $\mathrm{KH}_{2} \mathrm{AsO}_{4}$ ili Macquerova sol rabila se za konzerviranje kože i u bojadisarstvu. Uporaba arsenovih spojeva kao herbicida iz opravdanih je ekoloških razloga reducirana, no ipak se arsenska kiselina još uvijek upotrebljava u zaštiti drva.

lako se intenzivno upotrebljavao u 19. stoljeću u slikarstvu, kao lijek u Kini, otrov za muhe i sl., auripigment (slika 5) je zbog svoje otrovnosti i nepostojanosti zamijenjen kadmijevim žutim pigmentima. ${ }^{7}$ Poznati od davnina, auripigment i realgar kupovali su se u Veneciji u 17. stoljeću, jer je Venecija bilo dobro zemljopisno smještena kao europsko središte industrije bojenja tkanina i kao luka za trgovinu s Istokom. Upotrebljavali su se u europskom slikarstvu od 9. stoljeća do kraja 19. stoljeća (slika 6).

\section{Organski spojevi arsena i primjena u medicini}

Organoarsenovi spojevi imali su važnu primjenu u povijesti ljekarništva. U organoarsenovim spojevima arsen se pojavljuje u oba oksidacijska stanja: III i V. Poznato je preko 50 organoarsenovih spojeva u okolišu i živim organizmima. Budući da toksičnost spojeva nekog elementa ovisi o vrsti spoja (organski/anorganski), oksidacijskom stanju kemijskog elementa i sl., organoarsenovi spojevi pokazuju široku raznolikost u oblicima toksičnosti, a samim time u poteško-

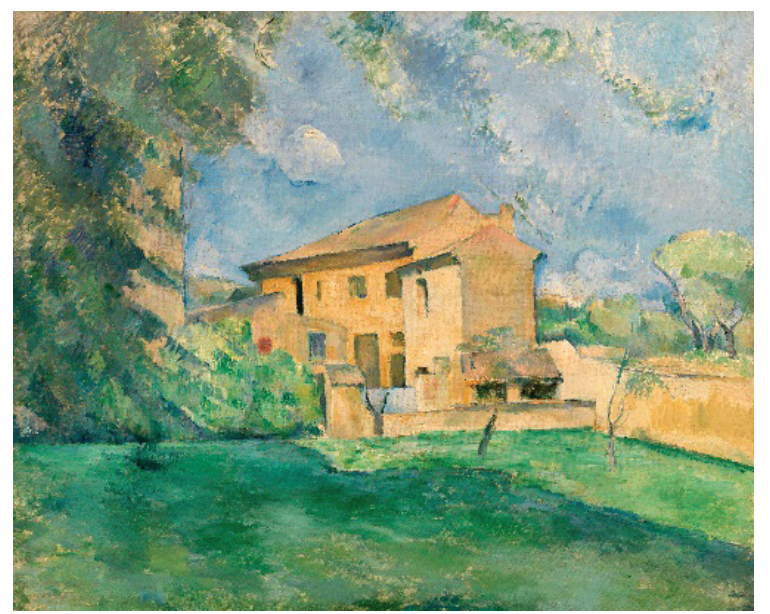

Prema: https://upload.wikimedia.org/wikipedia/commons/b/ bf/Paul C\%C3\%A9zanne - The Farm at the Jas de

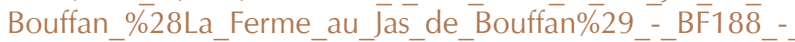
Barnēes_Foundation.jpg

Slika 4 - Paul Cezanne, Kesteni i farma, 1885., ulje na platnu, privatna kolekcija

Fig. 4 - Paul Cezanne, Chestnut trees and farm buildings, 1885, oil on canvas, private collection 

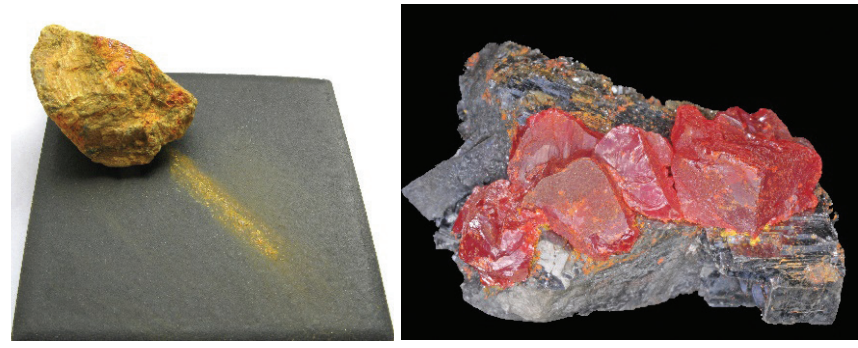

Prema: https://upload.wikimedia.org/wikipedia/commons/2/2a/ Orpiment_-_streak_color.jpg

https://upload.wikimedia.org/wikipedia/commons/f/f4/ Realgar\%2C_galena\%2C_orpiment.jpg

Slika 5 - Auripigment, $\mathrm{As}_{2} \mathrm{~S}_{3}$ i realgar, $\mathrm{AS}_{4} \mathrm{~S}_{4}$ (crveno)

Fig. 5 - Orpiment, $\mathrm{As}_{2} \mathrm{~S}_{3}$ and realgar, $\mathrm{As}_{4} \mathrm{~S}_{4}$

ćama otkrivanja individualnih učinaka na žive organizme. Zacijelo su metilirani oblici arsenovih(III) spojeva otrovniji od anorganskih spojeva arsena, a oni pak od metiliranih vrsta arsena(V) koje se lako izlučuju urinom. Arsen u metiliranim spojevima što sadrže sumpor pokazuje tiofilnost, sklonost stvaranju stabilne kovalentne veze arsen-sumpor (As-S), stoga su metilirani tio spojevi arsena otrovniji od okso oblika. Od "teških" metala izrazitu tiofilnost pokazuje živa. ${ }^{8}$

Smatra se da u voću, povrću, organizmima u vodi i mikroorganizmima arsen postoji u obliku organskih spojeva, dok se u sisavaca i u žitaricama više nalaze anorganski spojevi arsena. Arsenati i arsenov trioksid mogu izazvati karcinom pluća u sisavaca, dok organski trimetilarsin oksid može izazvati karcinom jetre u štakora. ${ }^{8}$

Toksičnost arsena u organizmima vezana je svakako uz oštećenja DNA različitim mehanizmima, dok je drugi put toksičnosti vezan uz interakciju s nekim enzimima, što može dovesti primjerice do apoptoze - programirane smrti stanice. Mehanizmi apoptoze, međutim, mogu biti osnova za uništavanje stanica, primjerice leukemije, u čemu se ogleda uporaba arsenovih spojeva kao potencijalnih lijekova protiv karcinoma. ${ }^{8}$ Dugotrajno izlaganje arsenu i trovanje arsenom može izazvati nedostatak vitamina A u organizmu. ${ }^{8}$

Arsen inaktivira sintezu NO u organizmu i time dovodi do smanjenja njegove bioraspoloživosti. ${ }^{7}$ Različiti učinci trovanja arsenom ustanovljeni su u životinja poput dijareje, konvulzija, pigmentacije kože, bolesti srca, moždanih udara, dijabetesa, respiratornih bolesti i karcinoma, no smatra se da takvi učinci moraju biti posljedica dugotrajnog izlaganja u ekstremnim uvjetima prisutnosti velikog onečišćenja arsenom i njegovim spojevima. ${ }^{8}$

Paul Ehrlich (1854. - 1915.; slika 7) njemački kemičar i liječnik, smatra se utemeljiteljem moderne hematologije te je 1908. dobio Nobelovu nagradu (zajedno s I. Mečnikovim) za svoj rad u području imunologije. Zajedno s Japancem Sahachirom Hatom sintetizirao je lijek protiv sifilisa, arsfenamin, organoarsenov spoj, poznat pod komercijalnim nazivom Salvarzan (slika 8). ${ }^{9}$ Hato je, u stvari, dokazao djelovanje tog spoja na bakteriju Treponema pallidum (uzročnik sifilisa). Salvarzan je bio prvi antibiotik i doista

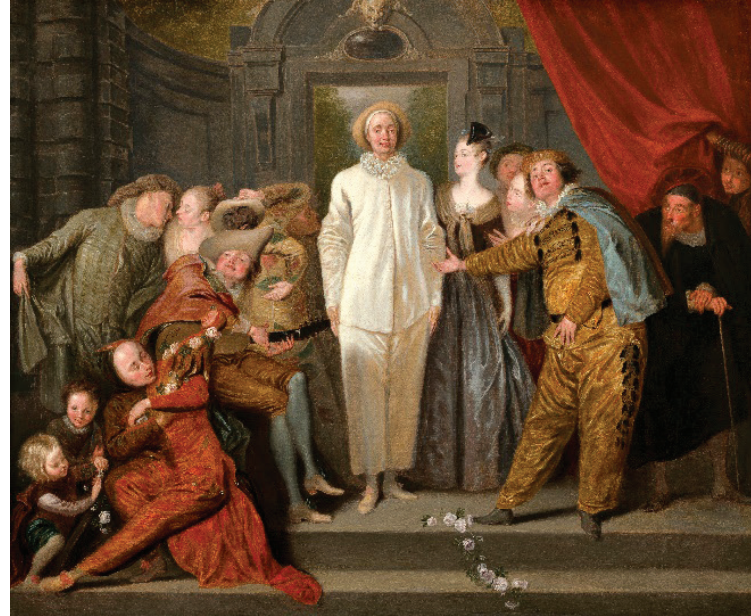

Prema: https://upload.wikimedia.org/wikipedia/commons/2/2e/ Antoine_Watteau__-_The_Italian_Comedians___Google_Art Project.jpg

Slika 6 - Antoine Watteau, Talijanski harlekini, 18. stoljeće, ulje na platnu, Nacionalna galerija umjetnosti, Washington, DC. Uporaba auripigmenta vidljiva je na kostimu desno na slici, a realgara na kostimu harlekina dolje lijevo na slici.

Fig. 6 - Antoine Watteau, The Italian Comedians, $18^{\text {th }}$ century, oil on canvas, National Gallery of Art, Washington, DC. Both orpiment and realgar have been found in the golden costume at the right, and the orange-red at the lower left.

revolucija u liječenju tada kronične, smrtonosne bolesti, sifilisa, iako ni Ehrlich ni Hato nisu mogli početkom 20. stoljeća predvidjeti niti definirati mehanizam djelovanja lijeka. Danas je poznato da je njegov mehanizam kompleksan i djeluje na DNA, RNA i proteine u bakteriji. Salvarzan je 40-ih godina 20. stoljeća, otkrićem drugih antibiotika, postao povijest medicine. ${ }^{10}$

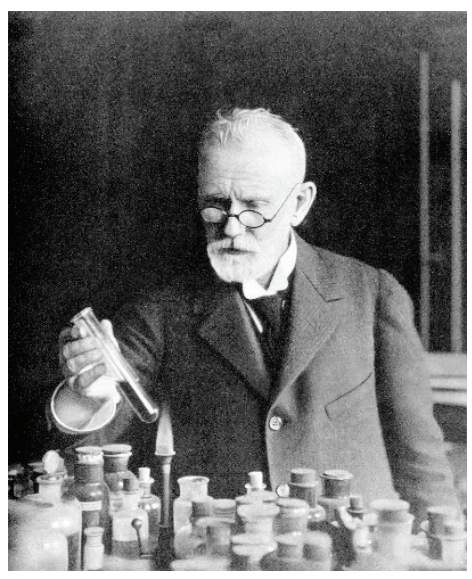

Prema: https://upload.wikimedia.org/wikipedia/commons/8/83/ Paul Ehrlich\%2C_c. 1910.jpg

Slika 7 - Paul Ehrlich, njemački kemičar i liječnik

Fig. 7 - Paul Ehrlich, German chemist and doctor 


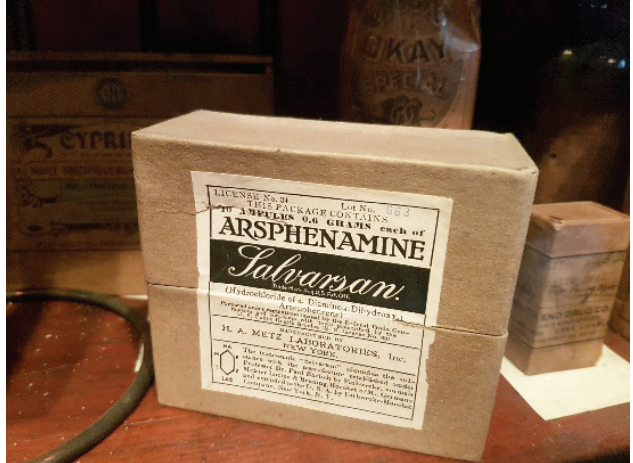

Prema: https://twitter.com/professor dave/ status/976550570671706112/photo/1.jpg

Slika 8 - Tvorničko pakiranje Salvarzana, lijeka koji sadrži organoarsenov spoj

Fig. 8 -Original package of Salvarsan, a medicine containing organo-arsenic compound

Temeljem reakcijskog mehanizma koji je primijenio, Ehrlich je pretpostavio da Salvarzan mora sadržavati dvostruku vezu As=As (model strukture A na slici 9), a tek 2005. godine došlo se do spoznaje da je struktura spoja u otopini temeljena na dvjema cikličkim vrstama formule: $(R A s)_{n}, s$ $n=3$ i $n=5$ (modeli strukture B i C na slici 9). ${ }^{11}$<smiles>Nc1cc(CNc2ccc(O)c(N)c2)ccc1O</smiles>
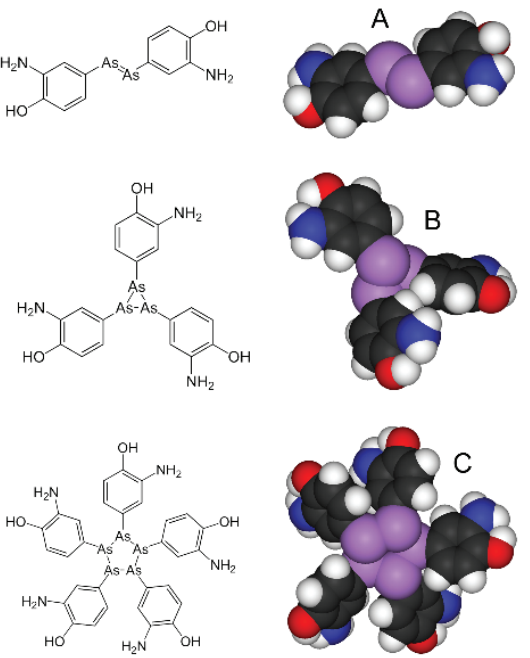

Prema: https://upload.wikimedia.org/wikipedia/commons/3/36/ Salvarsan-montage.png

Slika 9 - Ehrlichov pretpostavljeni model strukture (A) Salvarzana i otkrivene strukturne formule u otopini 2005. godine ${\text { (B i C modeli })^{10}}^{10}$

Fig. 9 - Ehrlich's supposed structural model (A) of Salvarsan, and structural formulae in solution (B and $\mathrm{C}$ models) ${ }^{10}$ discovered in 2005

\section{Protuotrovi i kelatna terapija}

Metodologija uklanjanja anorganskih oblika "teških" metala, posebice žive, olova i arsena temelji se na kelatacijskoj terapiji s kelatorima, višedentatnim ligandima koji stvaraju stabilne kelatne prstenove s kationom metala. To su antidoti (protuotrovi) što sadrže sumpor poput 2,3-dimerkaptojantarne kiseline (3-hidroksi-1,2-propanditiola; kolokvijalni naziv: DIMERKAPROL, BAL - "British anti-Lewisite" jer se upotrebljavao kao protuotrov pri trovanju kemijskim otrovom Lewisiteom) (slike 10 i 11) ili 2,3-dimerkaptopropansulfonske kiseline. Stvaranje stabilnih kelatnih kompleksa arsena s ligandima što sadrže sumpor kao donorni atom temelji se na stabilnoj vezi arsen-sumpor (tiofilnost arsena) i omogućuje lakšu ekstrakciju iz organizma. Sličan kemizam pokazuje živa također zbog svoje tiofilnosti.

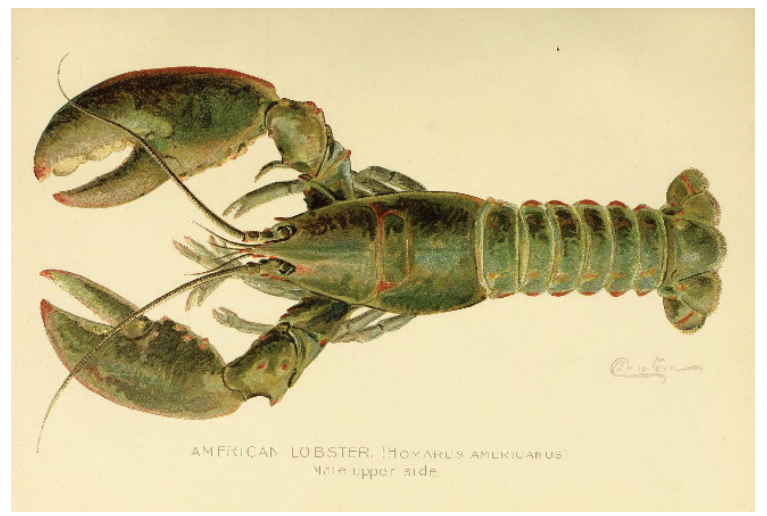

Slika 10 - Antidoti - spojevi koji se vežu za katione metala (poput kliješta raka, grč. chelae = kliješta) dajući stabilne koordinacijske spojeve ili komplekse (izlučuju se urinom)

Fig. 10 - Antidotes - compounds which coordinate metal cations (like crab's claw, Greek: chelae = claw) forming stable chelate complexes (extracted in urine)<smiles>O=C(O)C(S)C(S)C(=O)O</smiles><smiles>OCC(S)CS</smiles>

3-hidroksi-1,2-propanditiol dimerkaptojantarna kiselina

Slika 11 - Strukturne formule protuotrova u kelatnoj terapiji protiv trovanja arsenom

Fig. 11 - Structural formulae of antidotes in chelation therapy against arsenic toxication 


\section{Literatura \\ References}

1. N. N. Greenwood, A. Earnshaw, Chemistry of the Elements, Elsevier, 2. izdanje, 2012.

2. J. Emsley, Vodič kroz elemente (Građa prirode), Izvori, Zagreb, 2005., str. 47-51.

3. D. Grdenić, Povijest kemije, Novi Liber i Školska knjiga, Zagreb, 2001., str. 45-46.

4. S. Filipović, I. Lipanović, Opća i anorganska kemija, 2. dio, Školska knjiga, Zagreb, 1995. str. 739-753, 789-794.

5. J. Marsh, Account of a method of separating small quantities of arsenic from substances with which it may be mixed, Edinburgh New Philos. J. 21 (1836) 229-236.

6. (EMERALD GREEN AND SCHEELE'S GREEN u: Artists' Pigments A Handbook of Their History and Characteristics, Vol. 3, str. 219, ur.: E. W. Fitzhugh, National Gallery of Art, Washington, Archetype Publications, London, 1997.
7. Artists' Pigments A Handbook of Their History and Characteristics, Vol. 3, str. 47, ur.: E. W. Fitzhugh, National Gallery of Art, Washington, Archetype Publications, London, 1997.

8. O. Palacios and M. Capdevila, 3.04 Toxicology $(\mathrm{Pb}, \mathrm{Hg}, \mathrm{Cd}$, As, Al, Cr, and Others) u Comprehensive Inorganic Chemistry II: From Elements to Applications, Elsevier, 2013., Vol. 3., doi: https://doi.org/10.1016/B978-0-08-097774-4.003041.

9. N. Raos, Metali života-metali smrti, Školska knjiga, Zagreb, 2008., str. 74-85.

10. D. Doyle, Notoriety to respectability: a short history of arsenic prior to its present day use in haematology, Br. J. Haematol. 145 (2009) 309-317, doi: https://doi.org/10.1111/ j.1365-2141.2009.07623.x.

11. N. C. Lloyd, H. W. Morgan, B. K. Nicholson, R. S. Ronimus, The Composition of Ehrlich's Salvarsan: Resolution of a Century-Old Debate, Angew. Chem. Int. Ed. 44 (2005) 941944, doi: https://doi.org/10.1002/anie.200461471.

\section{SUMMARY \\ Arsenic and Its Compounds: Toxins, Pigments, and Medicine \\ Gordana Pavlović}

Arsenic is metalloid (element of the $15^{\text {th }}$ group of elements in the Periodic table of elements), and it is expected to form a series of compounds with different features regarding the type of chemical bond and structure. As a metalloid, it exhibits metallic and non-metallic character in chemical reactions.

Arsenic is able to form covalent compounds with elements of high electronegativity considering its Pauling's electronegativity coefficient, which is comparable to those of the non-metals, and is able to form stable As-As and As-C covalent bonds in compounds. Applications of arsenic compounds in the past have been various and multiple. The historical review of discoveries and usages of arsenic compounds clearly shows that development of arsenic chemistry is founded on scientific discoveries and improvement of science in general. The medicines in the past, and later, by scientific progress, many arsenic compounds had been rejected as toxins and replaced with more progressive, modern medicines, the features and usage of which are not based on experience of doctors and pharmacists any longer. The inorganic compounds of arsenic (especially some arsenic sulphide minerals) had been used as inorganic pigments in the art of painting.

Such examples of usage of compounds through history can be used in high school education as part of intercourse themes, thus joining the chemistry of arsenic with ecological and toxicological themes, as well as the history of art. The same goes for higher education, particularly within applied chemistry courses of arsenic or within the history of medicine and pharmacology.

\section{Keywords}

Chemistry of arsenic, arsenic compounds as toxins, pigments and medicine, ecotoxicology, chemistry education

Faculty of Textile Technology

University of Zagreb

Prilaz baruna Filipovića 28a

Review

10000 Zagreb, Croatia 